INVENTORY:Jurnal Akuntansi

ISSN 2597-7202 (Print); ISSN 2613-912X (Online)

Vol. 5, No. 2, Oktober 2021, Hal 127-134

Tersedia Online: http://e-journal.unipma.ac.id/index.php/inventory

\title{
Pengaruh Program Pemutihan Pajak dan Pembebasan Bea Balik Nama Terhadap Kepatuhan Wajib Pajak Kendaraan Bermotor
}

\author{
Lodang Prananta Widya Sasana ${ }^{1}$ I Gede Adi Indrawan ${ }^{2 *}$, Ryan Hermawan ${ }^{3}$
}

Progam Studi S1 Akuntansi, Universitas Pamulang, Tangerang Selatan, Indonesia

Email: dosen02227@unpam.ac.id ${ }^{1}$; dosen02257@unpam.ac.id ${ }^{2 *}$; ryanhermawan47@ gmail.com³

\section{Abstrak}

Penelitian bertujuan membuktikan pengaruh program pemutihan pajak kendaraan bermotor (PKB), dan pembebasan bea balik nama (BBNKB) terhadap kepatuhan wajib pajak kendaraan bermotor pada kantor SAMSAT Serpong, Kota Tangerang Selatan. Populasi penelitian adalah semua pengguna kendaraan bermotor yang terdaftar di SAMSAT Serpong Kota Tangerang Selatan. Metode yang digunakan dalam penelitian ini adalah accidental sampling yaitu teknik penentuan sampel secara kebetulan, yaitu siapa saja yang kebetulan bertemu dengan peneliti. Data dikumpulkan dengan metode survei dengan kuesioner, dan kuesioner memenuhi syarat untuk 100 kuesioner. Teknik analisis data menggunakan Analisis Regresi Linier Berganda. Hasil penelitian menunjukkan secara parsial tidak adanya pengaruh terhadap pemutihan pajak kendaraan bermotor (PKB) dan terdapat pengaruh pada pembebasan bea balik nama (BBNKB. Namun, secara bersamaan semua variabel berpengaruh pada kepatuhan wajib pajak kendaraan bermotor di SAMSAT Serpong Kota Tangerang Selatan. Penelitian ini juga menunjukan hasil pada uji determinasi, determinasi ini menjelaskan seberapa besar kemampuan model menjelaskan variasi variabel independen berpengaruh terhadap variabel dependen yang dinyatakan dalam presentase. Nilai koefisien determinasi sebesar $21,9 \%$ artinya persentase pengaruh variabel independent program pemutihan pajak $\left(\mathrm{X}_{1}\right)$ dan pembebasan bea balik nama $\left(\mathrm{X}_{2}\right)$ terhadap kepatuhan wajib pajak kendaraan bermotor $(\mathrm{Y})$ sebesar $21,9 \%$ sedangkan sisanya sebesar 78,1\% dipengaruhi atau dijelaskan variabel lain diluar dari variabel yang diteliti.

Kata kunci: Program Pemutihan Pajak; Pembebasan Bea Balik Nama; Kepatuhan Wajib Pajak Kendaraan Bermotor.

\section{The Influence of Tax Bleaching Program and Exemption of Transfer of Name Duty on Taxpayer Compliance Motor Vehicle}

\begin{abstract}
This study aims to prove the effect of the motor vehicle tax whitening program (PKB) and the exemption of transfer fees (BBNKB) on motor vehicle tax compliance at the SAMSAT Serpong office, South Tangerang City. The research population is all motorized vehicle users registered in SAMSAT Serpong, South Tangerang City. The method used in this study is accidental sampling, namely the technique of determining the sample by chance, that is, anyone who happens to meet the researcher. Data were collected by survey method with questionnaires, and the questionnaires were eligible for 100 questionnaires. The data analysis technique used Multiple Linear Regression Analysis. The results showed that partially there was no effect on the whitening of motor vehicle tax (PKB) and there was an effect on the exemption of transfer fees (BBNKB. However, simultaneously all variables affect the compliance of motor vehicle taxpayers in SAMSAT Serpong, South Tangerang City. This study also shows the results of the
\end{abstract}

DOI: 10.25273/inventory.v5vi2i.9376

Copyright (C) 2021 Penulis

Sume rights reserved. 
determination test, this determination explains how much the model's ability to explain the variation of the independent variable affects the dependent variable expressed in percentages. The coefficient of determination is $21.9 \%$ meaning the percentage of the influence of the independent variable on the tax whitening program $\left(X^{1}\right)$ and the exemption of transfer fees. $\left(X^{2}\right)$ to the compliance of motorized vehicle taxpayers $(Y)$ of $21.9 \%$ while the remaining $78.1 \%$ is influenced or explained by other variables outside of the variables studied.

Keywords: Tax Clearance Program; Exemption of Transfer of Name Duties; Motor Vehicle Taxpayer Compliance.

\section{PENDAHULUAN}

Pajak merupakan iuran wajib yang diberlakukan pada setiap pajak atas objek pajak yang dimilikinya dan hasil yang diterima dari pajak diserahkan kepada pemerintah. Jenis pajak yang ada di Indonesia diantaranya adalah Pajak penghasilan, Pajak Pertambahan Nilai, Pajak Bumi dan Bangunan, Pajak progresif, Pajak hiburan, Pajak hadiah, dan lain-lain. Pada hakekatnya, pembangunan nasional disuatu negara diselenggarakan oleh masyarakat bersama dengan pemerintah. Sehingga dalam mensukseskan pembangunan nasional, peranan penerimaan dalam negeri menjadi hal yang sangat penting mengingat sumber pembiayaan merupakan pendukung utama dalam pembangunan nasional. Pajak menurut UU No. 16 Tahun 2009 tentang perubahan keempat atas UU No. 6 Tahun 1983 tentang Ketentuan Umum dan Tata Cara Perpajakan Pasal 1 Ayat 1 ialah "kontribusi wajib kepada negara yang terhutang oleh setiap orang pribadi atau badan yang bersifat memaksa berdasarkan Undang-Undang, dengan tidak mendapatkan imbalan secara langsung dan digunakan untuk keperluan negara bagi sebesar-besarnya kemakmuran rakyat (Mardiasmo, 2018:3) Pajak merupakan sumber utama penerimaan negara yang menyumbang sekitar $70 \%$ dari seluruh penerimaan negara. Tanpa pajak, sebagian besar kegiatan negara akan sulit untuk dilaksanakan. Untuk menunjang itu semua, maka dilakukan pemungutan pajak. Pungutan pajak yang dilakukan oleh pemerintah, dilaksanakan sedemikian rupa agar tidak merugikan masyarakat, oleh karena itu diperlukan tarif pajak agar pemungutan pajak seimbang antara pemerintah dengan masyarakat sehingga tidak adanya pihak yang merasa dirugikan dan tidak terjadi kesalahan antara pemerintah dengan masyarakat.

Pajak kendaraan bermotor merupakan sumber pendapatan daerah yang sangat berpotensi, hal ini bisa dilihat dari peningkatan jumlah kendaraan yang dari tahun ketahun peningkatannya sangat signifikan. Hampir disetiap kepala rumah tangga, memiliki minimal 1 buah kendaraan bermotor sebagai asetnya, bahkan dari satu kepala rumah tangga ada yang memiliki lebih dari 1 atau 2 kendaraan bermotor. Jika setiap masyarakat atau wajib pajak patuh dalam melakukan pembayaran pajak kendaraan bermotor, maka potensi pendapatan daerah yang bersumber dari pajak kendaraan bermotor akan sebanding dengan meningkatnya jumlah kendaraan bermotor setiap tahunnya. Kepatuhan wajib pajak adalah suatu sikap terhadap fungsi pajak, berupa konstelasi dari komponen kognitif, efektif, dan konatif yang berinteraksi dalam memahami, merasakan dan berperilaku terhadap makna dan fungsi pajak (Yadnyana dan Sudiksa, 2011). Kepatuhan pajak merupakan salah satu penunjang yang mampu meningkatkan Pendapatan Asli Daerah. Berdasarkan atas permasalahan tersebut peneliti tertarik untuk melakukan penelitian dengan judul "Pengaruh Program Pemutihan Pajak dan Pembebasan Bea Balik Nama Terhadap Kepatuhan Wajib Pajak Kendaraan Bermotor”. METODE PENELITIAN

Penelitian ini menggunakan metode kuantitatif dan metode yang digunakan untuk menganalisis data adalah regresi linier berganda dengan serangkaian uji instrumen dan uji asumsi klasik. Penelitian ini dilakukan di SAMSAT Serpong Kota Tangerang Selatan yang dapat diambil data dan keterangan lainnya untuk bahan penelitian yang berkaitan dengan penelitian yang akan dilakukan. Penelitian yang dilakukan oleh penulis dalam menyusun skripsi ini bersifat kuantitatif, yaitu proses melakukan penelitian atas permasalahan untuk mengetahui 
pengaruh antara program pemutihan pajak dan pembebasan bea balik nama terhadap kepatuhan wajib pajak kendaraan bermotor sebagai variabel yang diteliti.

\section{HASIL DAN PEMBAHASAN}

\section{Uji Validitas}

Berdasarkan hasil pengujian validitas diketahui bahwa nilai $\mathrm{n}$ pada penelitian ini sebanyak 100 (jumlah responden), maka untuk nilai $\mathrm{r}_{\text {tabel }}=\mathrm{df}(\mathrm{n}-2)=100-2=98$ maka nilai rtabel n100 adalah 0,1966. Dapat disimpulkan bahwa pada pengujian validitas untuk seluruh pernyataan variabel Program Pemutihan Pajak (X1) dikatakan valid karena nilai $r_{\text {hitung }}>r_{\text {tabel }}$ dan nilai signifikansi kurang dari 0,05. Berdasarkan hasil pengujian validitas diketahui bahwa nilai n pada penelitian ini sebanyak 100 (jumlah responden), maka untuk nilai $\mathrm{r}_{\text {tabel }}=\mathrm{df}(\mathrm{n}-2)=100-2=98$ maka nilai $\mathrm{r}_{\text {tabel }} \mathrm{n} 100$ adalah 0,1966. Dapat disimpulkan bahwa pada pengujian validitas untuk seluruh pernyataan variabel Pembebasan Bea Balik Nama (X2) dikatakan Valid karena nilai $r_{\text {hitung }}>r_{\text {tabel }}$ dan nilai signifikansi kurang dari 0,05.

\section{Uji Reliabilitas}

Dari hasil uji dapat dilihat bahwa ketiga variabel dalam penelitian ini dinyatakan reliabel karena nilai Cronbach's Alpha masing-masing variabel lebih dibandingkan nilai standar umum yang dibentuk yaitu $>0,60$.

\section{Uji Normalitas}

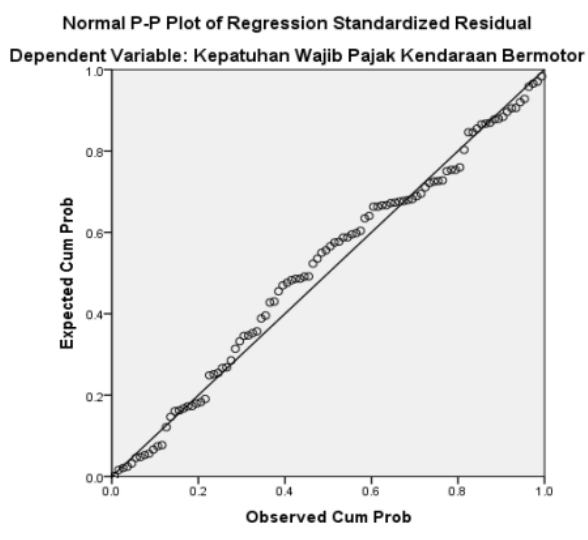

Gambar 1. Hasil Uji Normalitas Diolah Dengan SPSS.

Dengan melihat tampilan grafik normal P-Plot diatas dapat disimpulkan bahwa data menyebar disekitar garis diagonal dan mengikuti arah garis diagonal. Sehingga model regresi dapat dikatakan memenuhi asumsi normalitas. Adapun data dikatakan berdistribusi normal jika harga koefisien Asymp. Sig pada output Kolmogorov-Smirnov test > dari alpha yang ditentukan yaitu $5 \%$ (0.05). Berdasarkan hasil uji, diketahui bahwa nilai signifikan sebesar 0.123 artinya bahwa nilai Asymp.Sig lebih besar dari 0.05 maka data yang diuji adalah berdistribusi normal.

\section{Uji Multikolinearitas}

Berdasarkan nilai VIF yang diperoleh dari tabel 4.10 diatas menunjukan variabel bebas dalam model regresi tidak saling berkolerasi. Diperoleh nilai VIF dari masing-masing variabel bebas kurang dari 10 dan nilai Tolerance berada diatas 0,10 . Hal ini menunjukan tidak adanya korelasi antara sesama variabel bebas dalam model regresi dan dapat disimpulkan tidak terdapat masalah multikolenieritas diantara sesama variabel bebas dalam model regresi ini.

\section{Uji Heterokedastisitas}




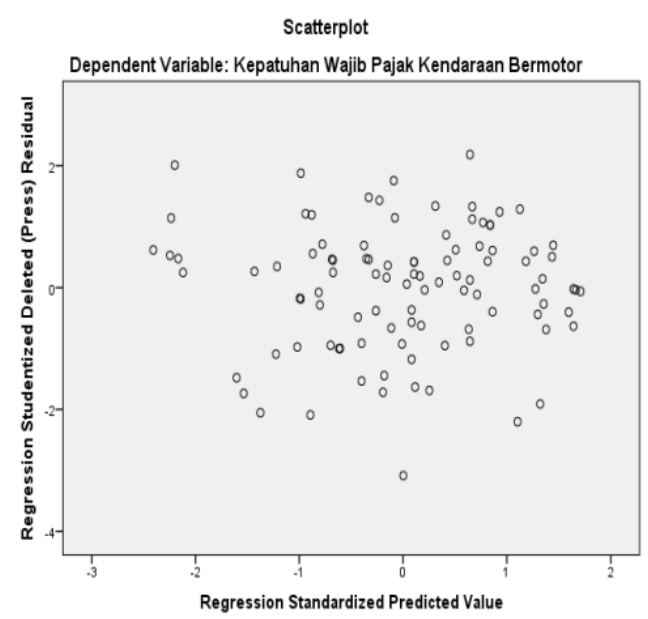

Gambar 2. Hasil Uji Heterokedastisitas Dengan SPSS.

Berdasarkan grafik Scatterplot diatas terlihat bahwa titik-titik menyebar secara acak dan tidak membentuk pola yang jelas, titik data menyebar diatas dan dibawah angka 0 pada sumbu Y. Dengan demikian dapat disimpulkan bahwa pada model regresi tidak terjadi heteroskedastisitas pada model regresi atau dengan kata lain model regresi adalah homoskedastisitas atau memiliki variance residu tetap dan model regresi layak digunakan untuk memprediksi Y. Selain dengan melihat grafik Scatterplot diatas, uji heterokedastisitas juga dapat dilakukan dengan cara uji glejser. Uji Glejser digunakan dengan meregresikan antara variabel independen dengan nilai absolut residualnya. Jika nilai signifikan antara variabel independen dengan absolut residual lebih dari 0,05 maka tidak terjadi masalah heteroskedastisitas. (Dwi Priyatno, 2012:158). Berdasarkan hasil uji, hasil regresi antara variabel independen dengan absolut residualnya menunjukan bahwa koefisien dari masingmasing variabel independen tidak ada yang signifikan (taraf signifikansi $>0,05$ ). Sehingga tidak menjadi masalah heteroskedastisitas.

\section{Uji Autokorelasi}

Dari hasil output Durbin-Watson diketahui bahwa nilai DW yang dihasilkan dari model regresi adalah 1,762. Dari nilai DW 1,762 nilainya akan dibandingkan dengan nilai tabel signifikan 5\% dengan jumlah sampel 98 (n) dan jumlah variabel independent $2(\mathrm{~K}=2)$ maka diperoleh nilai dU 1,712. Nilai DW 1,762 lebih besar dari batas (dU) yakni 1,712 dan kurang dari (4-dU) yaitu 4-1,712 $=2,288$. Sehingga dapat disimpulkan bahwa tidak terdapat autokolerasi.

\section{Uji Regresi Linear Berganda}

$$
Y=15,163+0,063 X_{1}+0,471 X_{2}
$$

Berdasarkan data diatas diterangkan bahwa, Konstanta (a) sebesar 15,163 menjelaskan apabila tidak ada variabel independent nilainya 0 , maka penerimaan pajak menjadi 15,163 kali satuan. Koefisien regresi program pemutihan pajak 0,063 menjelaskan bahwa apabila terjadi peningkatan variabel program pemutihan pajak sebesar satu satuan dengan asumsi lain konstan, maka besarnya kepatuhan wajib pajak kendaraan bermotor adalah 0,063 kali satuan. Koefisien regresi pembebasan bea balik nama adalah 0,471 menjelaskan bahwa apabila terjadi peningkatan variabel pembebasan bea balik nama yang dipersepsikan sebesar satu satuan dengan asumsi variabel lain konstan, maka besarnya kepatuhan wajib pajak kendaraan bermotor adalah 0,091 kali satuan. Untuk nilai signifikan variabel program pemutihan pajak adalah 0,601 dan untuk nilai signifikansi pembebasan bea balik nama adalah 0,000 . Hal ini menunjukan bahwa nilai variabel pemutihan pajak diatas 0,05 yang artinya variabel pemutihan pajak tidak berpengaruh signifikan terhadap kepatuhan wajib pajak kendaraan bermotor. Sedangkan variabel pembebasan bea balik nama berpengaruh 
signifikan terhadap variabel kepatuhan wajib pajak kendaraan bermotor, karena nilai variabel pembebasan bea balik nama dibawah 0,05 .

8. Hasil Uji Koefisien Determinasi $\left(\mathbf{R}^{2}\right)$

Dari data dapat diketahui bahwa nilai Adjusted $R$ Square adalah sebesar 0,219, nilai ini dikenal dengan koefisien determinasi (KD).

$$
\mathrm{KD}=0,219 \times 100 \%=21,9 \%
$$

Hal ini menunjukan bahwa persentase pengaruh variabel independent program pemutihan pajak dan pembebasan bea balik nama terhadap kepatuhan wajib pajak kendaraan bermotor sebesar 21,9\% sedangkan sisanya sebesar 78,1\% $(100 \%-21,9 \%=$ $78,1 \%$ ) dipengaruhi atau dijelaskan oleh variabel lain diluar dari variabel yang diteliti.

\section{Uji Statistik F (Simultan)}

Berdasarkan data dapat diterangkan bahwa didapat nilai $\mathrm{F}_{\text {hitung }}$ sebesar 14,917 $>\mathrm{F}_{\text {tabel }}=$ 3,09 dengan signifikansi 0,000, karena signifikansi lebih kecil dari 0,05 $(0,000<0,05)$ maka dapat disimpulkan bahwa variabel independent program pemutihan pajak, pembebasan bea balik nama berpengaruh secara simultan terhadap kepatuhan wajib pajak kendaraan bermotor.

\section{Uji Statistik t (Parsial)}

Berdasarkan hasi uji dapat dilihat bahwa program pemutihan pajak terhadap kepatuhan wajib pajak kendaraan bermotor menunjukkan tidak ada pengaruh yang signifikan. Sedangkan pembebasan bea balik nama terhadap kepatuhan wajib pajak kendaraan bermotor menunjukkan pengaruh yang signifikan. Berikut ini adalah hasil penjelasan mengenai pengaruh antar variabel independent terhadap kepatuhan wajib pajak. Variabel program pemutihan pajak dengan nilai $\mathrm{t}_{\text {hitung }}$ sebesar $0,525<1,984 \mathrm{t}_{\text {tabel }}$ dengan nilai signifikan lebih besar dari $0,05(0,05<0,601)$, maka dapat disimpulkan bahwa $\mathrm{H} 2$ ditolak yang berarti program pemutihan pajak tidak berpengaruh signifikan secara parsial terhadap kepatuhan wajib pajak kendaraan bermotor. Variabel pembebasan bea balik nama dengan nilai $t_{\text {hitung }}$ sebesar 3,788 $>1,984 t_{\text {tabel }}$, dengan nilai signifikan lebih kecil dari 0,05 $(0,05>$ 0,000), maka dapat disimpulkan bahwa kualitas pelayanan berpengaruh positif secara Parsial terhadap kepatuhan wajib pajak.

\section{Pengaruh Program Pemutihan Pajak dan Pembebasan Bea Balik Nama Terhadap Kepatuhan Wajib Pajak Kendaraan Bermotor}

Dari hasil analisis regresi linear bahwa pengaruh program pemutihan pajak dan pembebasan bea balik nama secara simultan berpengaruh terhadap kepatuhan wajib pajak kendaraan bermotor. Variabel-variabel independent tersebut berpengaruh positif dan signifikan terhadap variabel dependent. Besarnya pengaruh kedua variabel independent tersebut adalah sebesar $21,9 \%$ hal ini menjelaskan bahwa semakin tinggi atau rendahnya kepatuhan wajib pajak kendaraan bermotor oleh variabel program pemutihan pajak dan pembebasan bea balik nama sedangkan sisanya $78,1 \%$ dipengaruhi atau dijelaskan oleh variabel lain diluar dari variabel yang diteliti. Berdasarkan hasil pengujian yang telah dilakukan pada penelitian ini diketahui bahwa pada nilai $\mathrm{F}_{\text {hitung }} 14,917$ lebih besar dari $F_{\text {tabel }}$ 3,09 dengan nilai signifikan 0,000 nilai ini dibawah nilai signifikan 0,05 dapat dilihat pada tabel 4.14, maka dapat disimpulkan bahwa pengaruh program pemutihan pajak dan pembebasan bea balik nama secara bersama-sama berpengaruh positif dan signifikan terhadap kepatuhan wajib pajak kendaraan bermotor yang terdaftar di Kantor SAMSAT Serpong.

\section{Pengaruh Program Pemutihan Pajak Terhadap Kepatuhan Wajib Pajak \\ Kendaraan Bermotor}

Hasil Uji Hipotesis pertama menunjukan bahwa program pemutihan pajak tidak berpengaruh positif atau berpengaruh negatif terhadap kepatuhan wajib pajak kendaraan bermotor. Hal ini dapat dilihat dari nilai koefisien regresi dan nilai $t_{\text {hitung }}$ sebesar 0,525 yang jauh lebih kecil dari pada $t_{\text {tabel }}$ yaitu 1,984. Selain itu nilai signifikansi yang diperoleh 
adalah sebesar 0,601 yang berarti lebih dari 0,05 menunjukan bahwa variabel program pemutihan pajak berpengaruh negatif terhadap kepatuhan wajib pajak kendaraan bermotor. Hasil penelitian ini menunjukkan koefisien transformasi regresi sebesar 0,525 , hal ini menunjukkan bahwa rasio program pemutihan pajak tidak memiliki pengaruh positif terhadap kepatuhan wajib pajak kendaraan bermotor. Tidak adanya pengaruh positif yang ditunjukkan oleh program pemutihan pajak mengindikasikan bahwa apabila program pemutihan pajak mengalami kenaikan maka angka kepatuhan wajib pajak kendaraan bermotor tidak akan/belum tentu mengalami kenaikan pula, begitupun sebaliknya. Berdasarkan penjelasan tersebut, dapat disimpulkan bahwa program pemutihan pajak tidak berpengaruh positif terhadap kepatuhan wajib pajak. Dengan demikian Hipotesis yang menyatakan program pemutihan pajak terhadap kepatuhan wajib pajak kendaraan bermotor dinyatakan tidak terbukti pada kantor SAMSAT Serpong. Serta dapat disimpulkan juga bahwa hasil penelitian ini berbeda dengan hasil penelitian terdahulu yang dikatakan Jannah dan Fajriana (2018) bahwa penghapusan sanksi pajak berpengaruh positif terhadap kemauan membayar pajak.

\section{Pengaruh Pembebasan Bea Balik Nama Terhadap Kepatuhan Wajib Pajak Kendaraan Bermotor}

Dari hasil analisis regresi didapatkan bahwa pembebasan bea balik nama berpengaruh positif dan signifikan terhadap kepatuhan wajib pajak kendaraan bermotor dengan nilai $\mathrm{t}_{\text {hitung }}$ sebesar 3,788 yang jauh lebih besar dibandingan dengan $\mathrm{t}_{\text {tabel }}$ yaitu 1,984 dan nilai signifikan 0,000 lebih kecil dari 0,05 dapat dilihat pada tabel 4.13. hal ini menjelaskan bahwa pembebasan bea balik nama berpengaruh positif terhadap kepatuhan wajib pajak kendaraan bermotor untuk membayar pajak kendaraan bermotor terutama wajib pajak yang terdapat di kantor SAMSAT Serpong. Hasil penelitian menunjukkan koefisien transformasi regresi sebesar 3,788, hal ini menunjukkan bahwa rasio pembebasan bea balik nama memiliki pengaruh positif terhadap kepatuhan wajib pajak kendaraan bermotor. Pengaruh positif yang ditunjukkan oleh pembebasan bea balik nama mengindikasikan bahwa apabila pembebasan bea balik nama mengalami kenaikan maka angka kepatuhan wajib pajak kendaraan bermotor akan mengalami kenaikan pula, begitupun sebaliknya. Pembebasan bea balik nama sangat berpengaruh terhadap kepatuhan para wajib pajak untuk membayar pajak kendaraan bermotor yang dimilikinya. Dengan adanya pembebasan bea balik nama akan membuat para wajib pajak mau untuk membayar pajak atas bea balik nama secara cepat tanpa adanya biaya tunggakan sebelumnya. Dari hasil penelitian ini dapat dikatakan hasil penelitian yang dilakukan oleh Rahayu dan Amirah (2018) benar adanya bahwa pembebasan bea balik nama berpengaruh positif terhadap kepatuhan wajib pajak kendaraan bermotor.

\section{KESIMPULAN DAN SARAN}

Kesimpulan ini didasarkan pada hasil dari penelitian yang telah dilakukan dan menjawab semua yang tercantum dalam perumusan masalah sesuai dengan tujuan penelitian ini. Berdasarkan hasil dari penelitian yang telah dilakukan, maka dapat ditarik kesimpulan sebagai berikut :

1. Program pemutihan pajak dan pembebasan bea balik nama berpengaruh simultan terhadap kepatuhan wajib pajak kendaraan bermotor di kantor SAMSAT Serpong.

2. Program pemutihan pajak tidak berpengaruh positif terhadap kepatuhan wajib pajak kendaraan bermotor yang terdaftar di kantor SAMSAT Serpong.

3. Pembebasan bea balik nama berpengaruh positif dan signifikan terhadap kepatuhan wajib pajak kendaraan bermotor yang terdaftar di kantor SAMSAT Serpong. Hal ini dapat terlihat dengan adanya pembebasan bea balik nama akan membuat para wajib 
pajak mau untuk membayar pajak atas bea balik nama secara cepat tanpa adanya biaya tunggakan sebelumnya.

Berdasarkan hasil analisis dan pembahasan yang telah dijelaskan, serta kesimpulan yang telah dijabarkan sebelumnya, maka peneliti memberikan saran yang dapat dijadikan bahan masukan atau pertimbangan bagi pihak-pihak yang berkepentingan sebagai berikut :

1. Sanksi pajak harus disosialisasikan dengan baik kepada para wajib pajak agar wajib pajak dapat memahami hal-hal yang berkaitan dengan pelaksanaan sanksi pajak serta penyebab-penyebab dikenakannya suatu sanksi pajak terhadap wajib pajak. Sosialisasi ini dapat dilakukan dengan memberikan penyuluhan secara gratis bagi para wajib pajak baru atau secara berkala mengirimkan pemberitahuan mengenai pelaksanaan sanksi pajak. Atau juga bisa dilakukan dengan cara broadcast via social media dalam melakukan sosialisasi bahwa adanya sebuah kebijakan dari Pemerintah Daerah yaitu Program Pemutihan Pajak dan Pembebasan Bea Balik Nama Kendaraan Bermotor, agar banyak masyarakat yang mengetahuinya dan segera membayar pajak kendaraan bermotor tersebut.

2. Agar dapat mengetahui bagaimana sikap dan pengaruh para wajib pajak dalam kepatuhannya membayar pajak kendaraan bermotor yang terdaftar di kantor SAMSAT khususnya semua kantor SAMSAT yang ada di daerah Tangerang Selatan, maka untuk penelitian selanjutnya diharapkan dapat dilakukan penelitian dibeberapa kantor SAMSAT dengan tujuan untuk mengetahui dan membandingkan bagaimana pengaruh dan sikap para wajib pajak akan berpengaruh terhadap kepatuhan wajib pajak dalam membayar pajak kendaraan bermotor yang terdaftar dikantor SAMSAT Wilayah lainnya.

3. Agar para wajib pajak paham dan mengerti mengenai apa yang akan diteliti, maka untuk penelitian selanjutnya diharap dapat lebih proaktif dalam memberi kejelasan atas pernyataan-pernyataan yang diajukan dalam kuesioner yang akan dijawab para responden sehingga tidak menimbulkan perbedaan maksud dan tujuan yang telah ditentukan.

\section{DAFTAR PUSTAKA}

Aditia. (2015). "Pengaruh Kesadaran Wajib Pajak, Sanksi Perpajakan dan Akuntabilitas Pelayanan Publik Terhadap Kepatuhan Wajib Pajak kendaraan Bermotor". Skripsi S1 Akuntansi Universitas Pamulang.

Badan Pendapatan Daerah. 2010. Bea Balik Nama Kendaraan Bermotor. https://bprd.jakarta.go.id/bbn-kb/ (diakses tanggal 15 November 2019)

Cindy Apriani Chandra, dan Rizka Indri Arfianti. (2018). "Pengaruh Tingkat Pemahaman Pajak, Kualitas Pelayanan Publik, dan Sanksi Perpajakan Terhadap Kepatuhan Wajib Pajak Kendaraan Bermotor Roda Dua Di DKI Jakarta”. Jurnal Akuntansi : Institut Bisnis dan Informatika Kwik Kian Gie.

Cinti Rahayu, dan Amirah. (2018). Pengaruh program pemutihan pajak kendaraan bermotor, pembebasan bea balik nama kendaraan bermotor, dan sosialisasi perpajakan terhadap kepatuhan wajib pajak kendaraan bermotor. Jurnal Akuntansi : Universitas Pancasakti.

Direktorat Jendral Pajak. 2016. http://www.pajak.go.id. Diakses tanggal (2 September 2019)

Ghozali, Imam. (2016). Aplikasi Analisis Multivariate Dengan Program IBM SPSS 21. Semarang : Badan Penerbit Universitas Diponegoro.

Irawan. (2015). "Pengaruh Kesadaran WP dan Sanksi Administrasi Terdahap Tingkat Kepatuhan Pembayaran Pajak Kendaraan Bermotor”. Skripsi S1 Akuntansi Universitas Pamulang.

Mardiasmo. (2018). Perpajakan . Yogyakarta: CV Andi Offset.

Muslikhatul Ummah. (2008) " Pengaruh kesadaran wajib pajak, pengetahuan perpajakan dan 
pelayanan Fiskus terhadap kepatuhan wajib pajak kendaraan bermotor di kabupaten Semarang” Skripsi S1 Akuntansi Universitas Dian Nuswantoro Semarang.

Rusydi, Fathoni. (2011). Pengaruh Kualitas Pelayanan Terhadap kepatuhan Wajib pajak kendaraan Bermotor di Kota Batu" Skripsi S1 Akuntansi Universitas Brawijaya.

Siahaan, Marihot. 2010. Pajak dan Retrisusi Daerah Edisi Revisi. Jakarta : PT. Rajagrafindo Persada.

Sugiyono. (2017). Metode Penelitian Kuantitatif, Kualitatif, dan R\&D. Bandung: Alfabeta.

Supardi. 2013. Aplikasi Statistika Dalam Penelitian Edisi Revisi. Jakarta: CHANGE PUBLICATION.

Undang-Undang Republik Indonesia Nomor 28 Tahun 2007 Perubahan Ketiga Atas UndangUndang Nomor 6 Tahun 1983 Tentang Ketentuan Umum dan Tata Cara Perpajakan.

Wibowo. Eko Ari. 2019. Mulai 11 Maret 2019, Pajak Kendaraan di Banten dan Tangerang Naik. https://otomotif.tempo.co/read/1179511/mulai-11-maret-2019-pajak-kendaraandi-banten-dan-tangerang-naik/. (diakses tanggal 14 September 2019)

Widia Dwi Ratna Yanti. (2018). "Pengaruh Kualitas Pelayanan. Sanksi Pajak dan Kondisi Kuangan Wajib Pajak Terhadap Kepatuhan Wajib Pajak Kendaraan Bermotor". Skripsi S1 Akuntansi Universitas Negeri Surabaya.

William Ferry. (2017). "Pengaruh Pemutihan Pajak dan Kesadaran Wajib Pajak Terhadap Kepatuhan Wajib Pajak Kendaraan Bermotor”. S1 Akuntansi Universitas Katolik Musi Charitas Palembang.

Yadnyana, I Ketut. 2009. Pengaruh Moral dan Sikap Wajib Pajak pada Kepatuhan Wajib Pajak Koperasi di Kota Denpasar. Denpasar: Fakultas Ekonomi Universitas Udayana.

Yadnyana dan Sudiksa. 2011. Pengaruh Peraturan Pajak Serta Sikap Wajib Pajak Pada Kepatuhan Wajib Pajak Koperasi di Kota Denpasar. Buletin Studi Ekonomi, 17(2):h:197-206. Denpasar: Fakultas Ekonomi Universitas Udayana. 